\title{
Alpine ice-core evidence for the transformation of the European monetary system, AD 640-670
}

Christopher P. Loveluck ${ }^{1, *}$, Michael McCormick ${ }^{2}$, Nicole E. Spaulding ${ }^{3}$, Heather Clifford ${ }^{3}$, Michael J. Handley ${ }^{3}$, Laura Hartman ${ }^{3}$, Helene Hoffmann ${ }^{4}$, Elena V. Korotkikh ${ }^{3}$, Andrei V. Kurbatov ${ }^{3}$, Alexander F. More ${ }^{2,3}$, Sharon B. Sneed ${ }^{3} \&$ Paul A. Mayewski $^{3}$

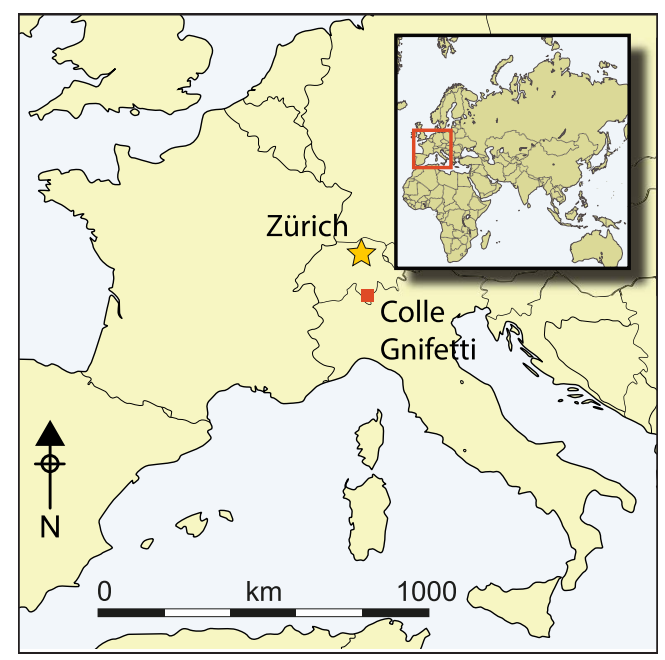

The seventh-century $A D$ switch from gold to silver currencies transformed the socioeconomic landscape of North-west Europe. The source of silver, however, has proven elusive. Recent research, integrating ice-core data from the Colle Gnifetti drill site in the Swiss Alps, geoarchaeological records and numismatic and historical data, has provided new evidence for this transformation. Annual ice-core resolution data are combined with lead pollution analysis to demonstrate that significant new silver mining facilitated the change to silver coinage, and dates the introduction of such coinage to $\mathrm{c}$. $A D$ 660. Archaeological evidence and atmospheric modelling of lead pollution locates the probable source of the silver to mines at Melle, in France.

Keywords: Europe, Colle Gnifetti, early medieval, ice core, lead pollution, silver coinage

\section{Introduction}

During the second half of the seventh century AD, the coin-using regions of North-west Europe switched from gold to silver currencies. This change was a key element in the social and economic transformations that resulted in increased long-distance trade, greater

1 Department of Classics and Archaeology, Humanities Building, University of Nottingham, Nottingham NG7 2RD, UK

2 Initiative for the Science of the Human Past and Department of History, Harvard University, 35 Quincy Street, Cambridge, MA 02138, USA

3 Climate Change Institute, Sawyer Environmental Research Building, University of Maine, Orono, ME 04469, USA

4 Institut für Umweltphysik, Im Neuenheimer Feld 229, Heidelberg University, Heidelberg D-69120, Germany

* Author for correspondence (Email: christopher.loveluck@nottingham.ac.uk)

(C) Antiquity Publications Ltd, 2018. This is an Open Access article, distributed under the terms of the Creative Commons Attribution licence (http://creativecommons.org/licenses/by/4.0/), which permits unrestricted re-use, distribution and reproduction in any medium, provided the original work is properly cited.

ANTIQUITY 92366 (2018): 1571-1585

https://doi.org/10.15184/aqy.2018.110 
specialisation and the growth of large port settlements (McCormick 2001; Loveluck 2013). Yet the sources of the silver that allowed the shift from gold to silver coinage have proven enigmatic. In the rare cases when scholars have addressed this issue, they have assumed that the silver came primarily from existing European stocks of residual Roman bullion, or that silver was imported from the Mediterranean region (Scull 2013: 546; Naismith 2014: 10). Recent archaeological exploration of an early medieval silver mine at Melle (Deux-Sèvres, France) and the isotopic profiling of its lead have indicated that exploitation of these deposits could have contributed to the epochal economic shift of the mid seventh century AD (Téreygeol 2010: 251, 259). Data on lead pollution from a new ice core at Colle Gnifetti, Switzerland (Figure 1), provides evidence of the renewed smelting of silver-lead ores from c. AD 640-670. This unambiguously shows that, alongside any residual pool of Roman bullion and imported metal, new mining facilitated the production of the last post-Roman gold coins-debased with increasing amounts of silver-and the new silver coinages that replaced them. The high-resolution ice-core record offers a new and independent chronology for renewed silver production in the early medieval west.

Previously published ice-core records, for example, from central Greenland (GRIP and GISP2), demonstrate trends in changing pollution and climate-driven atmospheric circulation in the northern hemisphere. These include evidence for the scale of northern hemisphere silver-lead smelting in the Roman period, and for the influences of climate change on marine and terrestrial air masses from the 'Medieval Climate Anomaly' (c. AD 950-1250) to the 'Little Ice Age' (c. AD 1400-1700) (Mayewski et al. 1993; Hong et al. 1994; Kreutz et al. 1997). In contrast, the new Alpine ice core from Colle Gnifetti $\left(45^{\circ} 55^{\prime} \mathrm{N}, 7^{\circ} 52^{\prime} \mathrm{E}\right)$ provides a lead pollution record from the heart of Western Europe, with a high-resolution annual layer-counted chronology covering the last 2000 years (More et al. 2017; Bohleber et al. 2018). The core documents the 'signatures' of a range of macro-economic and societal changes that are not evident in those Greenland ice cores published to date. One of these signatures is the renewed mining and smelting of silver-lead ores in Western Europe during the seventh century AD. Analysis of atmospheric circulation patterns, provided by Climate Re-analyzer ${ }^{\mathrm{TM}}$ visualisation software (Climate Change Institute, University of Maine$\mathrm{CCI}$ ), illuminates the potential sources that delivered lead aerosol to Colle Gnifetti. We compare the ice-core evidence to other pollution records and archaeological and historical data from specific mining sites and regions (Figure 1). We then consider the implications of this new evidence for understanding the transformation of the economy of mid seventhcentury early medieval Europe.

\section{The Colle Gnifetti ice core: analytical methods and chronological framework}

The ice core was extracted in August 2013 from the Colle Gnifetti glacier (Monte Rosa, 4450m asl) in the Swiss-Italian Alps. The drill site was located on the north-facing slope of the glacier, on a flow-line trending towards its eastern flank (Figure 2). The core was drilled to bedrock, is $72 \mathrm{~m}$ long and has an estimated net surface accumulation of approximately $0.2 \mathrm{~m}$ of water equivalent per year. The chronological resolution derived from different elements and the measurement of lead pollution was established in a two-phase process: firstly, through continuous

(C) Antiquity Publications Ltd, 2018 


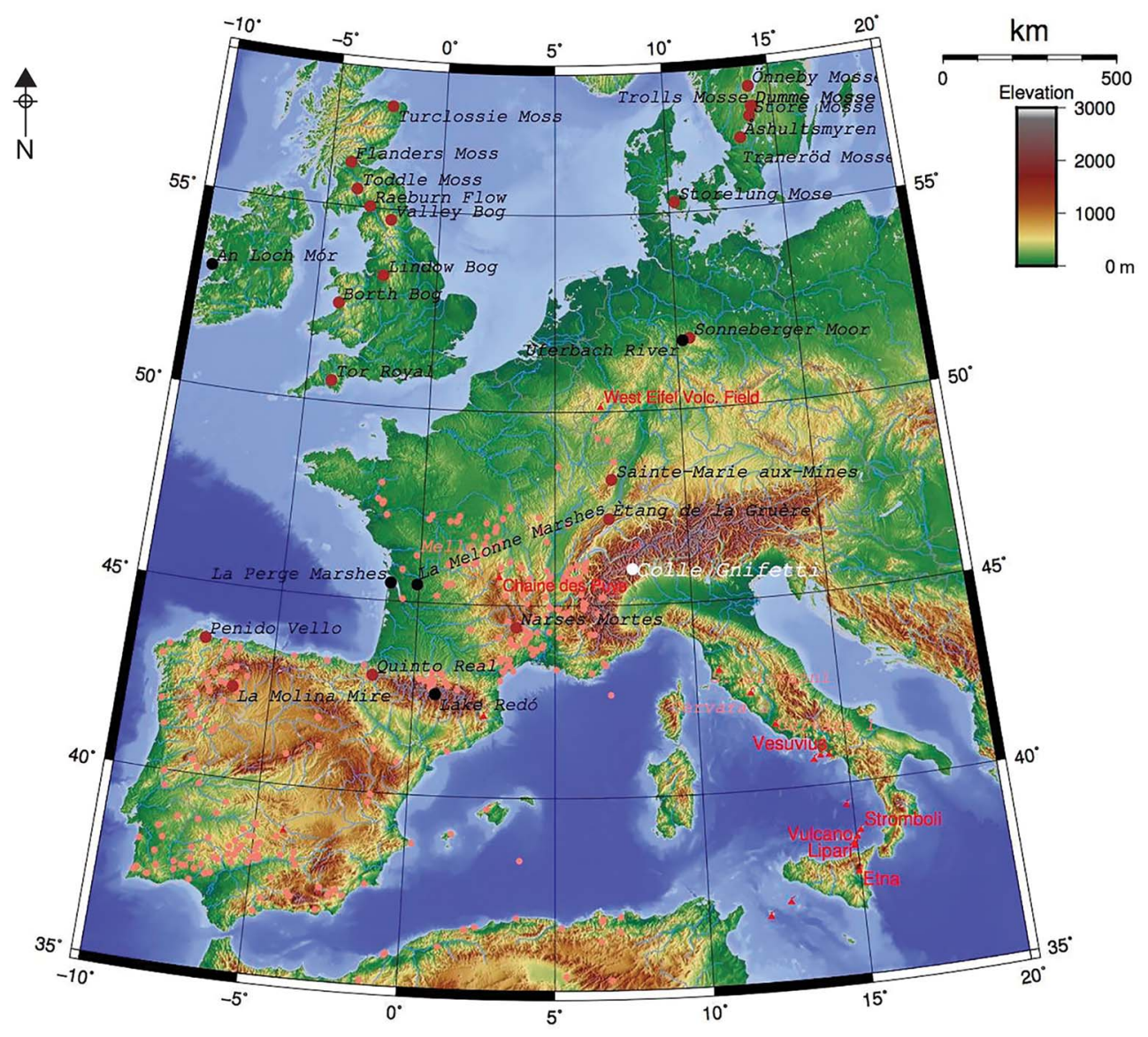

GMJ $2016 \operatorname{Jan} 27$ 20:32:31

Figure 1. Location of the Colle Gnifetti ice-core and other geo-archaeological pollution records across Western Europe (figure by A.V. Kurbatov).

flow analysis and high-resolution discrete inductively coupled plasma mass spectrometry (ICP-MS) and ion chromatography; and, secondly, by annual layer-counting using ultra-high resolution laser ablation inductively coupled plasma mass spectrometry (LA-ICP-MS). (For the detailed methodological procedures, materials, specification and calibration details of the instruments used, see Sneed et al. 2015; More et al. 2017; Bohleber et al. 2018.)

Ultra-high resolution sampling of the ice core by LA-ICP-MS occurred at intervals of 120 microns, and was undertaken at CCI (Sneed et al. 2015). This new method allows the counting of highly compressed and thinned annual ice layers not previously resolved by existing centimetre-resolution analyses of ice cores. Figure 3 shows an example of annual layer-counting with LA-ICP-MS for the years AD 700-704, using atmospheric dust-derived calcium (see also the online supplementary material (OSM) S2.1). Layers were identified as local maxima in the calcium profile, corresponding to mostly summer snow preservation (Preunkert et al. 2000: 998). Elements such as iron were used to corroborate further the calcium-

(C) Antiquity Publications Ltd, 2018 

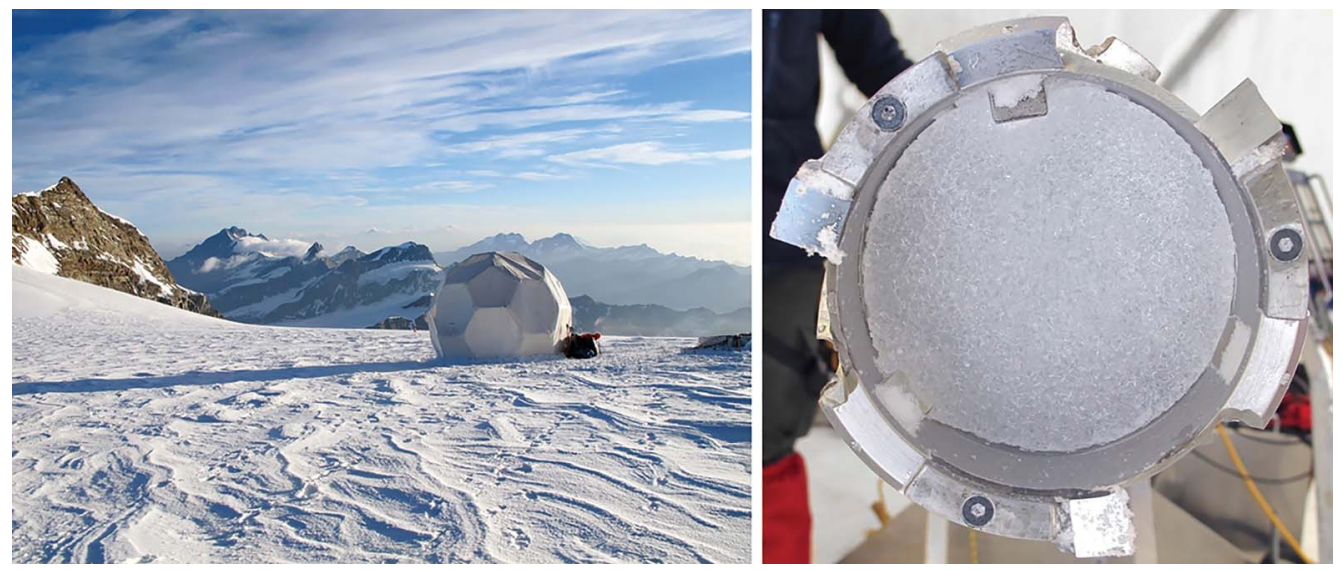

Figure 2. Left) the drilling site (under the dome tent) on Colle Gnifetti; right) a section of the core (photographs by N.E. Spaulding).

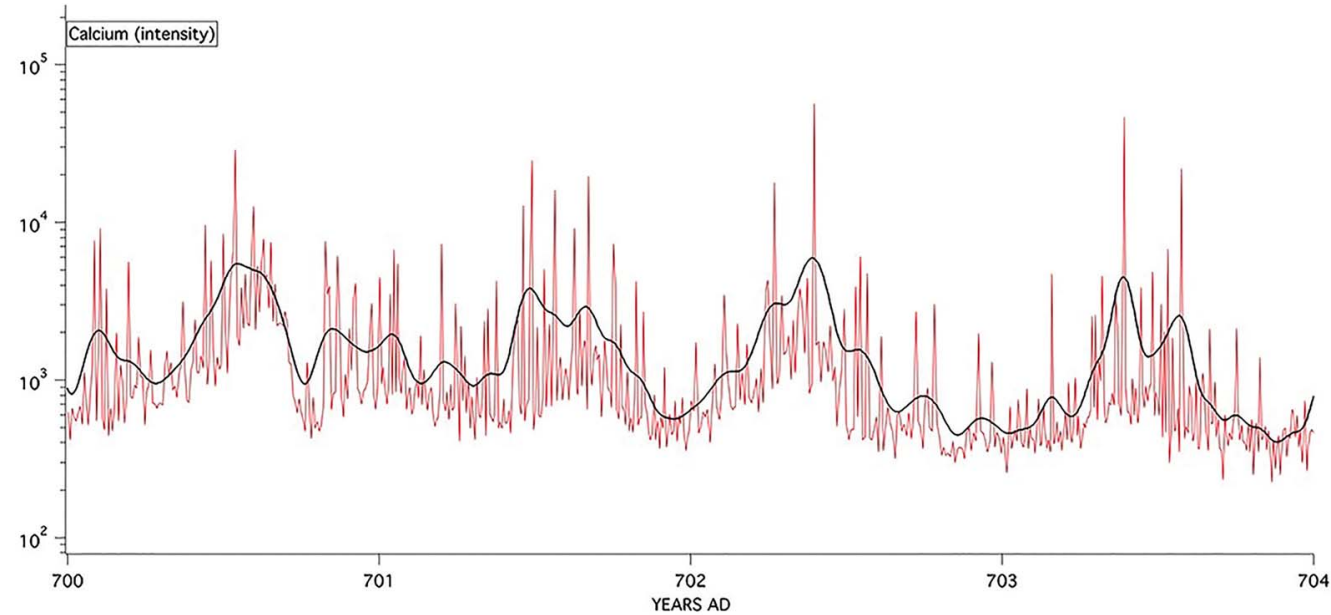

Figure 3. Example of annual layer-counting on the Colle Gnifetti ice core for the years AD 700-704, using ultra-high-resolution LA-ICP-MS analysis of calcium intensity (figure by P.A. Mayewski).

based layer-counting. Since AD 1900, known time-markers, such as documented major Saharan dust events, were used to constrain the ice-core chronology. For the most recent 800 years or so, further corroboration was provided by direct time series comparisons with a neighbouring Colle Gnifetti ice core, dated with conventional centimetre-resolution analysis (Schwikowski et al. 2004). The discrete liquid-based ICP-MS measurement of multi-element (including lead) concentrations through the new core was also conducted at CCI, with an average resolution of $45 \mathrm{~mm}$ from a water stream generated by the continuous melter system (Bohleber et al. 2018).

The ultra-high-resolution time series allows the application of the Colle Gnifetti layercounting procedure back to at least the beginning of the first millennium $\mathrm{AD}$. The layer-counting methodology had a theoretical error margin of \pm 72 years at $c$. AD 600, without absolute dating markers to tie the chronology more closely (Bohleber et al. 2018). The chronology has been (C) Antiquity Publications Ltd, 2018 
greatly refined and established to address the research questions of this paper by the use of three absolute chronological markers that reduce this theoretical error margin to an estimated \pm 10 years or fewer. The first absolute marker is provided by the Black Death signal (see More et al. 2017). More et al. (2017) have demonstrated that despite a theoretical error of 35-40 years, between 1330 and 1370, the total collapse in lead pollution in layer-counted deposits, from 1349 to 1353, matches exactly the absolute chronology from textual sources for the Black Death epidemic, especially in Britain - the probable source of the pollution record for that period.

The second absolute marker comes from the geochemical evidence of the massive eruption of the Icelandic Eldgjá volcano between AD 934 and 939 (Thordason et al. 2001). The discrete ICP-MS data from Colle Gnifetti present a large bismuth peak at AD 945, which probably indicates the Eldgjá eruption. Although this also corresponds with a large sulphate peak at Colle Gnifetti, sulphate cannot be used as a reliable volcanic marker there, as most of it arrives in the form of gypsum (calcium sulphate) as dust (Schwikowski et al. 2004). A similar contribution of sulphate from dust was encountered in the Mount Everest ice core, where bismuth was also used as the independent volcanic marker (Kaspari et al. 2007: 1-2). The identification of the large bismuth increase at $c$. AD 945 at Colle Gnifetti with the Eldgjá eruption corresponds closely with its eruption interval, suggested as AD 934 in Alpine tree rings and at 939 in the GISP2 Greenland ice core (Baillie \& McAneney 2015: 112). The occurrence of other Icelandic volcanic signals in the Colle Gnifetti core has also been confirmed by the publication of Icelandic tephra recovered from it (Luongo et al. 2017), and is further emphasised by the new discovery below.

The third absolute marker is provided by analysis of newly discovered tephra particles from the Colle Gnifetti core that are chemically very similar to the tephra from the NEEM-2011-S1 Greenland ice core-shard QUB-1859 (Sigl et al. 2015; see OSM S1). The latter has been interpreted as tephra corresponding to the AD 536 volcanic event. The NEEM-2011-S1 core is tied chronologically to the GICC05 Greenland ice core, which fixes the NEEM-2011 and the Colle Gnifetti tephra to AD 536 2 (Sigl et al. 2013). The Colle Gnifetti annual layer-counting chronology places the AD 536-event tephra at $\mathrm{AD} 500$, suggesting a maximum error of 36 years at $\mathrm{AD} 536$ in the initial chronology (Bohleber et al. 2018). Recounting of the annual layers from the Eldgjá event to AD 536 has ascertained that, due to poorly defined annual layers, the counting error occurred between c. AD 500 and 600. The current theoretical error margin between $\mathrm{AD} 600$ and 700 is estimated at a maximum of \pm 10 years, and less through the eighth and ninth centuries $\mathrm{AD}$.

\section{Lead pollution: potential sources, historical events and societal trends}

The lead pollution record reflected in the new discrete ICP-MS time series at Colle Gnifetti provides a unique archive of changes in the smelting of silver-lead ores for Western Europe, transported to the western Alps by long-distance, high-level tropospheric and low-level regional winds over the last 2000 years (More et al. 2017: fig. 1). It can be compared to less temporally resolved records provided by peat and lake sediment cores. The most reliably dated of the latter indicate a post-Roman decline in lead emissions through the fifth and early sixth centuries (Le Roux et al. 2004: 507; Kylander et al. 2005: 480-81). By the mid sixth

(C) Antiquity Publications Ltd, 2018 


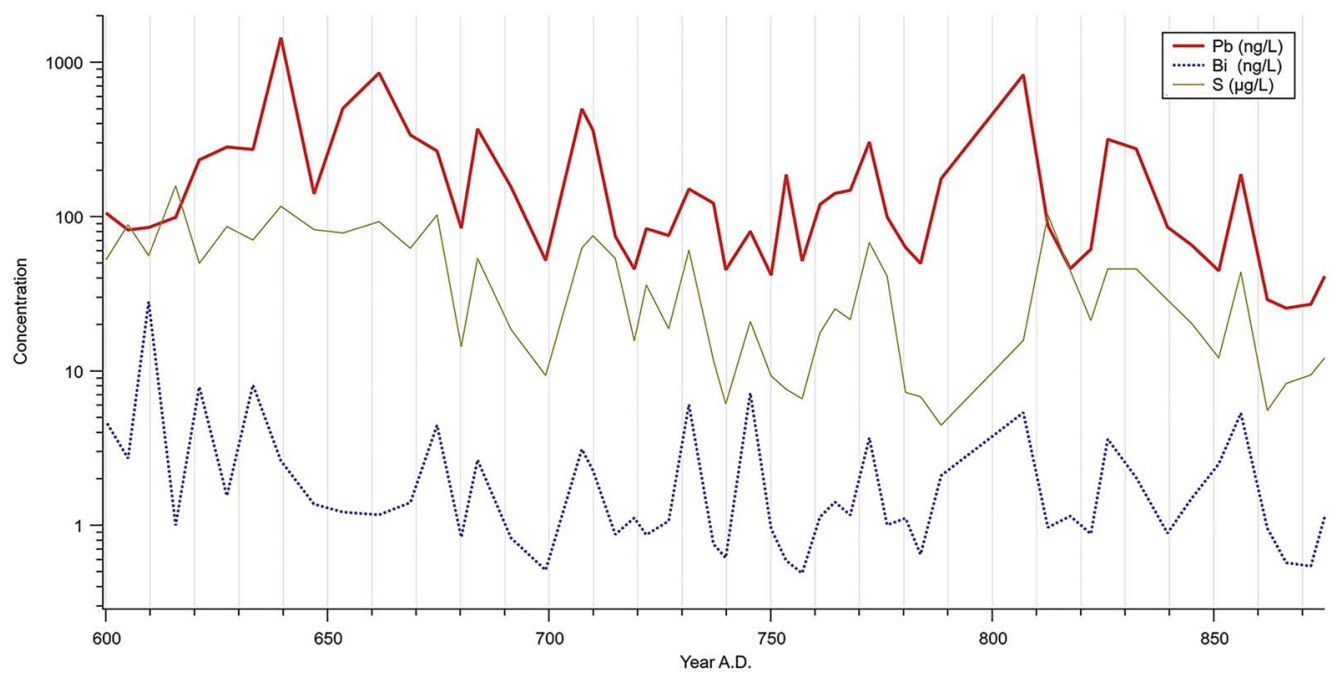

Figure 4. Changing pollution deposition by concentration (log scale) of lead, bismuth and sulphur in the Colle Gnifetti ice core, between $A D 600$ and 875, from high-resolution discrete ICP-MS (figure by H. Clifford).

century, these records show a further steep decline across Western Europe. This possibly reflects the first ravages of the Justinianic plague pandemic and sudden climate change attributable to the 'Late Antique Little Ice Age', with commensurate decline in demand (Büntgen et al. 2016: 234). From around AD 600, the discrete ICP-MS measurements show detailed patterns of fluctuating lead deposition at Colle Gnifetti.

A significant increase in lead aerosol pollution is evident from the mid AD 620s, which peaks in $640 \pm 10$ (at 639; see OSM S2.2, but between 630 and 650 with the \pm 10 -year error margin, see Figure 4). Lead deposition then reaches two further peaks in AD $660 \pm 10$ and $695 \pm 10$. Measurements of bismuth and sulphur were compared with the lead record to ascertain whether their probable origin was anthropogenic or volcanic. Both bismuth and sulphur occur in Western European lead-silver galena ores and are released as by-products during the smelting and cupellation processes (L'Héritier et al. 2015: 58-59). They can, however, also be released with lead during volcanic eruptions. Most importantly, the lead peaks in $\mathrm{AD} 640$ and 660 do not mirror high bismuth measurements and are, therefore, probable anthropogenic signals (Figure 4).

The sudden reappearance of large anthropogenic lead peaks between $\mathrm{AD} 640$ and $660 \pm 10$ implies significant new smelting of galena ores in one or more regions capable of delivering pollution to the north-facing slopes of the Alps. Atmospheric circulation modelling using Climate Re-analyzer ${ }^{\mathrm{TM}}$ and averaged data from June, July and August 1979-2014 (Figure 5) suggests that air mass delivery to the drill site was most probably from the west. The closest source region lies in modern-day France. Other climate analyses over shorter durations have also shown the probability of delivery of aerosol pollutants from Britain to Colle Gnifetti (More et al. 2017: fig. 4). The circulation patterns suggest a reduced probability of pollution from Spain or known areas of later medieval mining, such as Sardinia and Tuscany. It has not yet been possible to measure lead isotopes to attempt to distinguish lead mining sources, due to the small size of the ice samples from the Colle Gnifetti core. While isotope analysis of peat (C) Antiquity Publications Ltd, 2018 


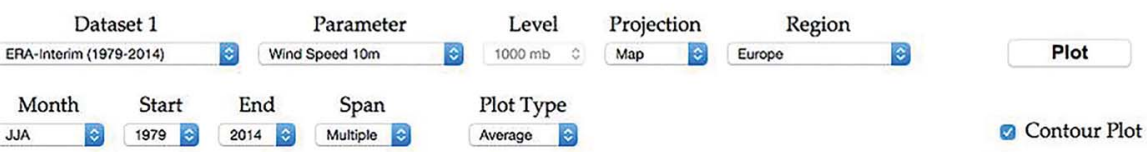

ECMWF ERA-Interim

JJA 1979-2014

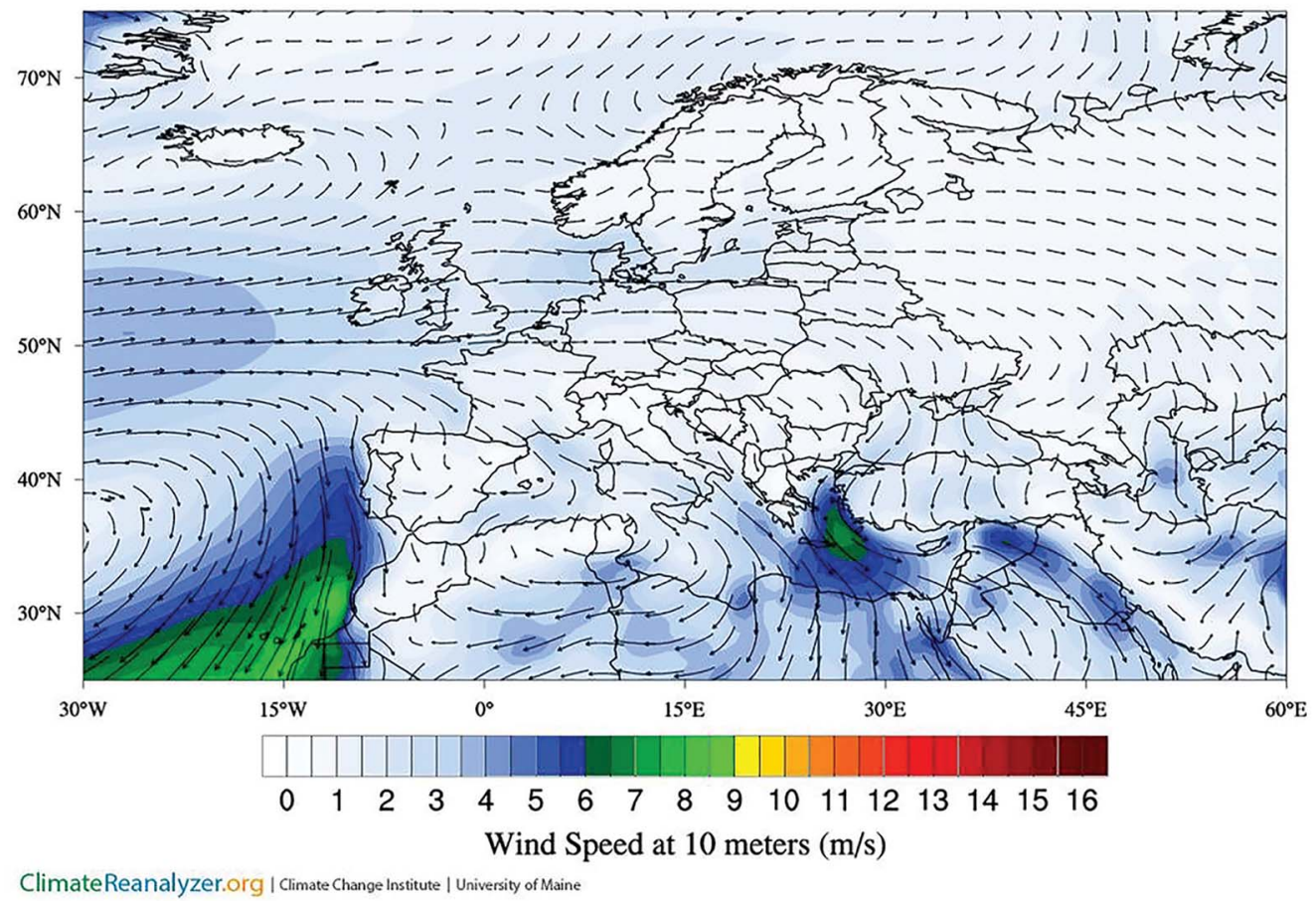

Figure 5. Climate Re-analyzer ${ }^{\mathrm{TM}}$ model showing air-mass delivery from the west to Colle Gnifetti, between June, July and August 1979-2014 (CCI).

and lake sediments has been possible, sourcing has been fraught with difficulties. Similar geology among different source regions within Europe often produces lead metal and aerosol pollution with overlapping isotope characteristics, rendering the sources indistinguishable. Furthermore, scrap metal from different origins was added during cupellation and casting, thereby mixing isotopic signatures (Baron et al. 2009; Pedersen et al. 2016: 157-59).

To date, only one place west of Colle Gnifetti has yielded archaeological evidence supported by radiocarbon dates that demonstrates mid seventh-century AD mining and smelting of silver-lead galena ore. That place is the site of the paramount silver mines of Western Europe prior to the tenth century, located at Melle (Deux-Sèvres, France; Figure 6). Thousands of coins were produced by the miners and moneyers at Melle during its ninthcentury zenith (Bruand 2002; Coupland 2014). Twenty years of research at Melle have produced a firm understanding of the mine galleries, and of the ore-processing, -smelting and -cupellation methods used to separate silver from lead (Téreygeol 2007). Twenty-six radiocarbon dates from charcoal range from the fifth to the later tenth centuries, although

(C) Antiquity Publications Ltd, 2018 


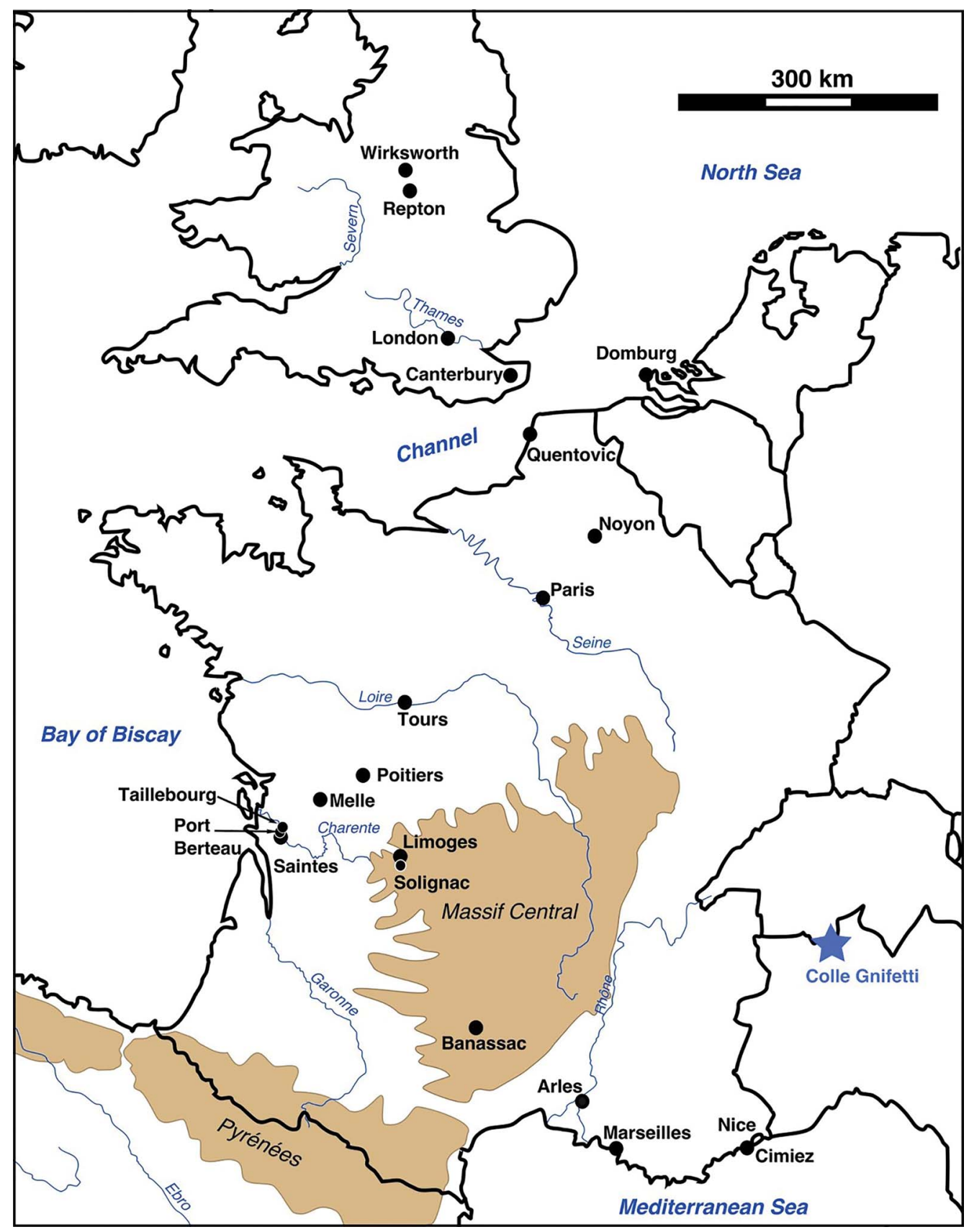

Figure 6. Places and sites discussed in the text with archaeological or textual evidence relating to the period, c. AD 640725 (figure by S. Troadec \& C.P. Loveluck).

the majority of the trees converted into charcoal date from the early seventh century onwards (Téreygeol 2010: 253, fig. 2). Isotopic studies show that different mints across western France struck numerous pennies that used silver from Melle from a point in (C) Antiquity Publications Ltd, 2018 

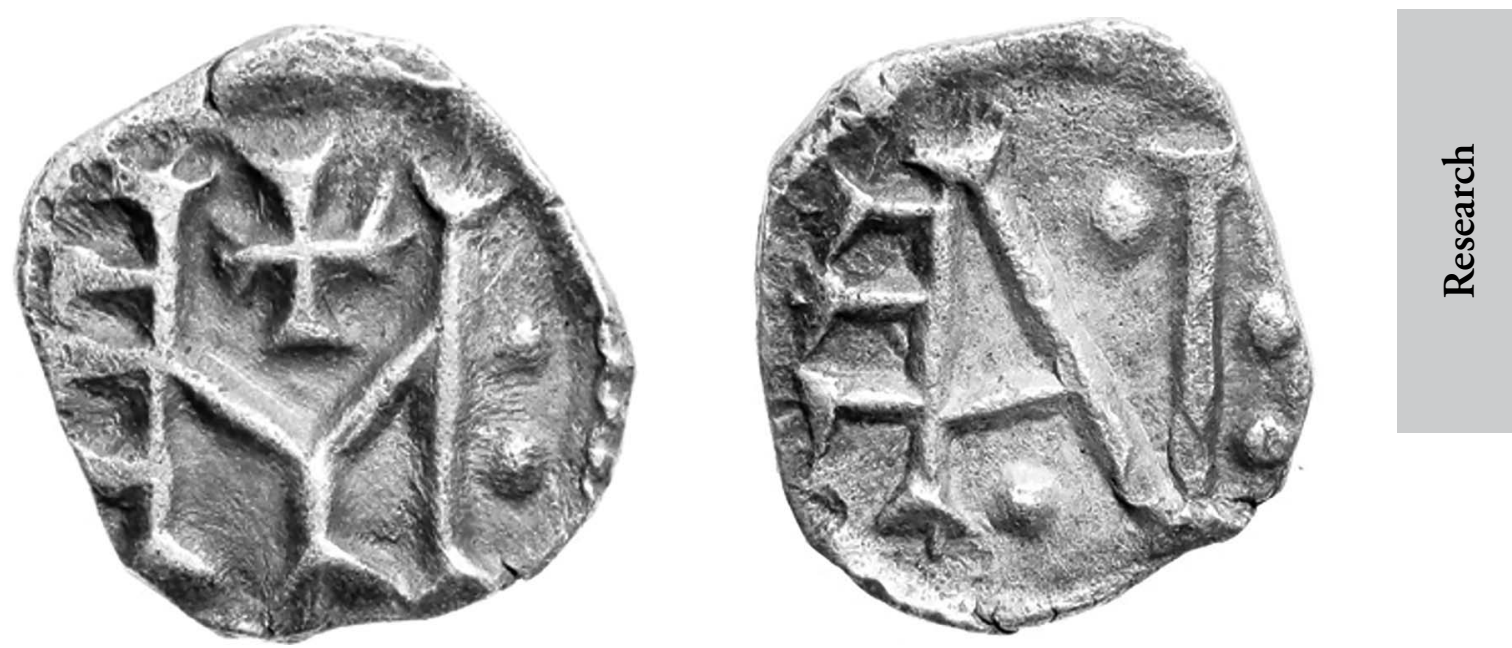

Figure 7. Penny minted at Melle (left: obverse; right: reverse), probably struck from c. 660. Found at Ashford, Kent (EMC 2016.0039, image courtesy of T. Abramson).

time dated numismatically to $c$. AD 675 onwards (Clairand \& Téreygeol 2009; Téreygeol 2010: 253-59; Figures 6-7).

An origin from Melle for the seventh-century lead pollution finds further support in the close correspondence between the lead deposition patterns and known smelting and minting at Melle during the Carolingian period, particularly from $c$. AD 790-875. Figure 4 shows ice-core lead peaks at $\mathrm{AD} 805 \pm 10$ and $825 \pm 10$, dates which fall within the numismatic chronology for the minting of the Metullo coinage issue of Charlemagne at Melle, between AD 793 and 814 (Coupland 2015: 61), and the Melle issues of his son, Emperor Louis the Pious, between AD 816 and 823 (Coupland 2014: 265-68). The sharp drop in lead deposition in AD 850 \pm 10 mirrors the recorded sack of Melle by Vikings in $\mathrm{AD} 848$ and a civil war in the region between Charles the Bald and Pepin of Aquitaine during the mid 850s (Grat et al. 1964: 55;

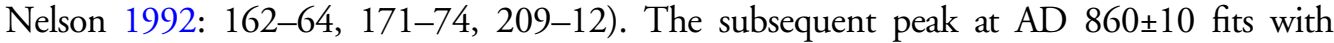
renewed minting of Charles's Metullo coinage at Melle in the 860 s, prior to the political and economic fragmentation of the west Frankish kingdom following his death in 877 . The correspondence between known minting and political events affecting Melle and the Colle Gnifetti ice-core record is startling, even with the time error margin of the discrete ICP-MS data. It reinforces the probability that Melle was the source for the seventh-century peaks.

Mining regions to the west of Colle Gnifetti, in Spain and France, have not yet yielded highresolution evidence of silver-lead ore smelting between $c$. AD 550 and 700 (Kylander et al. 2005; Martinez-Cortizas et al. 2013). Only in one case-at Lake Redó in the Pyrenees-do sediments show a peak in lead concentration at $c$. AD 660. These, however, were not deposited in annual varve layers, and so are dated absolutely within the radiocarbon error margin (approximately \pm 150 years when stated, with a rise in lead beginning in $c$. AD 467 and ending in $c .1105$ ); there are also high levels of lead in local granitic rocks around Redó (Camarero et al. 1998: 442-44). The earliest radiocarbon dates from archaeological surveys of over 70 lead mining/ smelting sites, and peat evidence from central and southern France, show new lead mining

(C) Antiquity Publications Ltd, 2018 
only from the eleventh to thirteenth centuries onwards (Baron et al. 2005, 2006; Bailly-Maitre et al. 2013). In Britain, the surprising wealth in silver and gold within furnished graves in the Peak District (Derbyshire), from c. AD 640-660, may hint at contemporaneous lead and silver extraction (Loveluck 1995: 90). Currently, however, the earliest unambiguous early medieval evidence for lead production in Britain comes from an Anglo-Norman rendition of a charter dated to $\mathrm{AD} 835$, when an aristocrat, Humberht, was obliged to pay a rent in lead for land he held at Wirksworth (Kelly \& Brooks 2013: 636-38; Figure 6). Exploitation of silver-lead sources in Germany cannot be proven until the ninth century, when very limited mining occurred in the Harz Mountains region, prior to its later zenith from $c$. AD 950-1050 (Kempter \& Frenzel 2000: 100).

\section{Context, purpose and implications of new silver production, c. AD 640-680}

The lead peak dated to $c$. AD $640 \pm 10$ at Colle Gnifetti occurred at a crucially important moment in the post-Roman monetary history of Western Europe. A recent archaeometric study has confirmed that, beginning in the reign of Dagobert I (AD 629-639), the gold content of the tremissis coinage issued in the Merovingian kingdoms of Gaul declined progressively and substantially. This was due to the intentional addition of silver, and is unambiguously shown by the concurrent presence of significant amounts of lead in the coinage arising from galena ore processed to extract new silver (Blet-Lemarquand et al. 2010: 189). Measurements by proton activation analysis (PAA, 35 coins) and by LA-ICP-MS (9 coins, one of which was also assayed by PAA) have indicated that coins struck by the Provence and Banassac mints declined from 92-94 per cent gold to 31-61 per cent at $c$. AD 640 (Blet-Lemarquand et al.2010: 179-82). The swiftness and extent of this change argue against a measure to compensate for the gradual depletion of gold content that might accompany 'wear and tear' and repeated recycling, or a diminishing gold supply (Grierson \& Blackburn 1986: 95, 109). Instead, they suggest a conscious decision to increase the amount of gold, albeit alloyed with silver, available for striking. Expanding money supply may, in turn, hint at an increased demand for coinage-a consideration that numismatists could test by estimating from die patterns whether the volume of production did indeed increase in these years (Metcalf 2006: 383-88). The end of Byzantine gold subsidies to the Frankish kings $c$. AD 600 — exacerbated by declining or less favourable Mediterranean trade from the AD 620s-has been suggested as the trigger for the sudden adulteration with silver of the Merovingian gold coinage, a situation also observed in Anglo-Saxon England c. AD 640 (Blet-Lemarquand et al. 2010: 191, 195; Williams 2010: 58). In any event, the new alloy coins used silver, and the Colle Gnifetti ice core confirms a surge in lead pollution in $c$. AD $640 \pm 10$. This reflects lead-silver freshly mined and smelted to produce at least a proportion of this new coinage.

The second large seventh-century peak at $660 \pm 10$ occurs when pure silver issues replaced gold-silver alloy coinage. Numismatists have estimated that the first silver coinage in the western Merovingian kingdoms was minted c. AD 675 (Depeyrot 2001: 6; Lafaurie \& Pilet-Lemière 2003: 11). If, as seems probable, Ebroin — the 'mayor of the palace'-decided on the shift to silver, the change will have occurred between $c . \mathrm{AD} 658$ and his death in c. 680 (Ewig 1986); the new coins are mentioned in texts from 682 (Grierson \& Blackburn 1986:

(C) Antiquity Publications Ltd, 2018 
94). The use of the earliest silver coins—-known today as deniers in France (here called pennies) — could conceivably have overlapped with the last use of the gold-silver alloy issues (McCormick 2018: 439). Numismatists have also suggested a contemporaneous change in England c. 675-80, from the use of debased Anglo-Saxon gold coins to silver replacements, known as sceattas (Archibald 2013; Gannon 2013: 93-97). A new chronology for dating Anglo-Saxon furnished graves, involving high-resolution carbon-dating, artefact seriations and Bayesian modelling, however, challenges the numismatic date for the first sceattas; the earliest sceattas (almost exclusively series B) from graves were dated by the modelling to c. AD 660 (Hines \& Scull 2013; Scull \& Naylor 2016: 213-14).

An association between the radiocarbon-based Bayesian date for the first Anglo-Saxon silver coins (c. AD 660) and contemporaneous lead-silver smelting, most probably occurring at Melle in France, probably reflects an almost simultaneous minting of silver coinage in France and England from the early $\mathrm{AD}$ 660s. Its immediate economic and social impact may have been limited by both geography and the range of social actors who found it useful. Merovingian mints concentrated in three regions: around the Mediterranean ports of Arles and Marseilles; within central-western France, between Melle, Poitiers and Tours; and in the Paris basin, extending into upper Burgundy (Depeyrot 2001; Kluge 2013; Figure 6). Although the minting location(s) of series B sceattas are currently unknown, their initial use was largely confined to south-eastern England. Deposition of these early silver coinages soon concentrated in the key exchange zones of the Channel and southern North Sea coasts of Europe. Early Merovingian pennies have been found at the seasonal beach-trading settlement at Domburg, Walcheren, in the Scheldt estuary (Dhénin \& Schiesser 2007: 294), and in the south-east of England (Figure 7). Series B sceattas occur in small numbers in the Pas-de-Calais and Picardy; and in the vicinity of the port of Quentovic (Leroy 2009: 201); they are also found in a hoard of mainly Merovingian pennies, buried in $c$. AD 720 at Cimiez, near Nice, on the Mediterranean coast of France (Grierson \& Blackburn 1986: 142-43; Figure 6). Key features of these silver coinages were their high silver content and close similarity in weight (Metcalf \& Northover 1989: 106), making them interchangeable from the North Sea to the Mediterranean.

\section{Conclusions}

Preliminary analysis of the Colle Gnifetti ice core, using ultra-high-resolution layer-counting chronology, high-resolution analysis of pollution proxies for metal production and atmospheric circulation modelling to assess source regions, permits a new appreciation of macroeconomic and societal change during the seventh century AD. Integrated analysis of the icecore data with other environmental, archaeological, numismatic and textual records from Western Europe has identified a pollution record c. AD $640 \pm 10$ and $660 \pm 10$, probably stemming from new, large-scale silver mining and bullion production in those years. The evidence indicates that the mines at Melle in western France were the most probable source. The Colle Gnifetti ice core provides a chronology independent of archaeological and numismatic dates for the two major monetary transformations of seventh-century North-west Europe. In the early AD 660s, the port settlements of the Channel and North Sea were in their infancy, whereas by the 680s, multiple lines of evidence show that the large ports at London

(C) Antiquity Publications Ltd, 2018 
(Lundenwic) and Quentovic were firmly established (Bede HE IV.22; Colgrave \& Mynors 1969; Malcolm et al. 2003; Lebecq et al. 2010). The striking of silver coinage from $c$. AD 660, rather than from c. 675-680 as previously suggested by numismatists, allows this more utilitarian silver currency an extra 15-20 years of use within the mercantile agency that made these ports vibrant by $c$. 685. Combined with ongoing advances in numismatic studies and archaeological research, high-precision environmental records provide a unique new insight into the dynamics of metal and coin production, and contemporaneous social transformations in the early medieval West.

\section{Acknowledgements}

This is contribution six of the 'Historical Ice Core' project funded by the Arcadia Fund (AC3862) of Peter Baldwin and Lisbet Rausing, whose support we gratefully acknowledge. C.L. also thanks the History Department, Dumbarton Oaks, and the Initiative for the Science of the Human Past, Harvard University, for funding a Visiting Professorship for this research, and the University of Nottingham. Ice-core and tephra analyses were conducted at the W.M. Keck Laser Ice Facility and ICP-MS laboratory at CCI, funded by the W.M. Keck Foundation and the National Science Foundation (PLR-1042883, PLR-1203640, PLR-1142007). We also thank Pascal Bohleber for his research on the ice-core chronology. The Colle Gnifetti core was collected by a team from the Institut für Umweltphysik, Universität Heidelberg, CCI-University of Maine and the Climate and Environmental Physics Institute, University of Bern, with support from the Alfred-Wegener-Institute, Bremerhaven. Thanks are also due to Solenn Troadec, Martin Allen and Tony Abramson.

\section{Supplementary material}

To view supplementary material for this article, please visit https://doi.org/10.15184/aqy. 2018.110

\section{References}

Archibald, M. 2013. Reply, in J. Hines \& A. Bayliss (ed.) Anglo-Saxon graves and grave-goods of the sixth and seventh centuries $A D: a$ chronological framework (Society for Medieval Archaeology Monograph 33): 512-15. Leeds: Maney.

Baillie, M.G.L. \& J. McAneney. 2015. Tree ring effects and ice core acidities clarify the volcanic record for the first millennium. Climate of the Past 11: 105-14. https://doi.org/10.5194/cp-11-105-2015

Bailly-Maître, M.-C., N. Minivielle-Larousse, E. Kammenthaler, T. Gonon \& G. Guionova. 2013. L'exploitation minière dans la vallée du Chassezac (Ardèche): le plomb, l'argent et le cuivre au Moyen Âge (XIeXIIIe siècle). Archéologie médiévale 43: 47-76.

Baron, S., M. Lavoie, A. Ploquin, J. Carignan, M. Pulido \& J.-L. De Beaulieu. 2005. Record of metal workshops in peat deposits: history and environmental impact on the Mont Lozère Massif, France. Environmental Science \&
Technology 39: 5131-40. https://doi.org/10.1021/es0481651

Baron, S., J. Carignan, S. Laurent \& A. Ploquin. 2006. Medieval lead making on Mont Lozère Massif (Cévennes, France): tracing ore sources using Pb isotopes. Applied Geochemistry 21: 241-52. https://doi.org/10.1016/j.apgeochem.2005.09. 005

Baron, S., C. Le-Carlier, J. Carignan \& A. Ploquin. 2009. Archaeological reconstruction of medieval lead pollution: implications for ancient metal provenance studies and paleopollution tracing by $\mathrm{Pb}$ isotopes. Applied Geochemistry 24: 2093-101. https://doi.org/10.1016/j.apgeochem.2009.08.003

Blet-Lemarquand, M., M. Bompaire \& C. Morrisson. 2010. Platine et plomb dans les monnaies d'or mérovingiennes. Revue numismatique 166: 175-98.

Bohleber, P., T. Erhardt, N. Spaulding, H. Hoffmann, H. Fischer \& P.A. Mayewski. 2018. Temperature and mineral dust variability recorded in two low accumulation Alpine ice

(C) Antiquity Publications Ltd, 2018 
cores over the last millennium. Climate of the Past 14: 21-37.

https://doi.org/10.5194/cp-14-21-2018

BRUAND, O. 2002. Voyageurs et marchandises aux temps carolingiens: les réseaux de communications entre Loire et Meuse aux VIIIe et IXe siècles (Bibliothèque du Moyen Âge 20). Brussels: Éditions De Boeck Université.

BÜNTGEN, U., V.S. MygLAN, F. Charpentier Ljungqvist, M. McCormick, N. Di Cosmo, M. Sigl, J. Jungclaus, S. Wagner, P.J. Krusic, J. Esper, J.O. Kaplan, M.A.C. De VaAn, J. Lutterbacher, L. Wacker, W. Tegel \& A.V. Kirdyanov. 2016. Cooling and societal change during the Late Antique Little Ice Age from 536 to around $660 \mathrm{AD}$. Nature Geoscience 9: 231-36. https://doi.org/10.1038/ngeo2652

Camarero, L., P. Masqué, W. Devos, I. Ani-Ragolta, J. Catalan, H.C. Moor, S. Pla \& J.A. Sanchez-Cabeza. 1998. Historical variations in lead fluxes in the Pyrenees (northeast Spain) from a dated lake sediment core. Water, Air and Soil Pollution 105: 439-49. https://doi.org/10.1023/A:1005005625972

Clairand, A. \& F. Téreygeol. 2009. L'atelier monétaire de Melle (Deux-Sèvres): premières conclusions, in A. Clairand \& D. Hollard (ed.) Numismatique et archéologie en Poitou-Charentes, Actes du colloque de Niort, 7-8 décembre 2007: 31-47. Paris: Séna.

Colgrave, B. \& R.A.B. Mynors. 1969. Bede's ecclesiastical history of the English people. Oxford: Oxford University Press.

Coupland, S. 2014. The use of coin in the Carolingian Empire in the ninth century, in R. Naismith, M. Allen \& E. Screen (ed.) Early medieval monetary history. Studies in memory of Mark Blackburn: 257-93. London: Routledge.

- 2015. Attributing the Melle coins of Charlemagne (768-814) and Charles the Bald (840-877), particularly single finds from the Netherlands. Jaarboek voor Munt-en Penningkunde 102: 61-96.

Dереутот, G. 2001. Le numéraire mérovingien: l'âge du denier (Collection Moneta 22). Wetteren: Moneta.

Dhénin, M. \& P. Schiesser. 2007. Oboles mérovingiennes. Revue numismatique 163: 283313.

Ewig, E. 1986. Lexikon des Mittelalters (volume 3). Turnhout: Brepolis.
Gannon, A. 2013. Syllogue of coins of the British Isles 63. British Museum Anglo-Saxon coins, part 1: early Anglo-Saxon coins and Continental silver coins of the North Sea, c. 600-700. London: British Museum.

Grat, F., J. Vieillard \& S. Clémencet (ed.). 1964. Annales de Saint-Bertin. Paris: Société de l'histoire de France.

Grierson, P. \& M. Blackburn. 1986. Medieval European coinage 1, the Early Middle Ages $\left(5^{\text {th }}-10^{\text {th }}\right.$ centuries $)$. Cambridge: Cambridge University Press.

Hines, J. \& C. Scull. 2013. The chronological models and the numismatic chronology: a discussion, in J. Hines \& A. Bayliss (ed.) Anglo-Saxon graves and grave-goods of the sixth and seventh centuries $A D$ : a chronological framework (Society for Medieval Archaeology Monograph 33): 509-12. Leeds: Maney.

Hong, S., J.-P. Candelone, C.C. Patterson \& C.F. Boutron. 1994. Greenland ice evidence of hemispheric lead pollution two millennia ago by Greek and Roman civilizations. Science 265: 1841-43. https://doi.org/10.1126/science.265.5180.1841

Kaspari, S., P.A. Mayewski, S. Kang, S. Sneed, S. Hou, R. Hooke, K. Kreutz, D. Introne, M. Handley, K. Maasch, D. Qin \& J. Ren. 2007. Reduction in northward incursions of the South Asian monsoon since $1400 \mathrm{AD}$ inferred from a Mt. Everest ice core. Geophysical Research Letters 34(16). https://doi.org/10.1029/2007GL030440

Kelly, S.E. \& N.P. BrooKs. 2013. Charters of Christ Church Canterbury. Oxford: Oxford University Press.

Kempter, H. \& B. Frenzel. 2000. The impact of early mining and smelting on local tropospheric aerosol detected in ombrotrophic peat bogs in the Harz, Germany. Water, Air and Soil Pollution 121: 93-108.

https://doi.org/10.1023/A:1005253716497

KLuge, B. 2013. Die merowingischen Monetarmünzen: Epochenwandel im Münzwesen-Münzwesen im Epochenwandel. Numismatische Handreichungen für Historiker, in J. Jarnut \& J. Strothmann (ed.) Die Merowingischen Monetarmünzen als Quelle zum Verständnis des 7. Jahrhunderts in Gallien: 33-92. Paderborn: Von Zabern.

Kreutz, K.J., P.A. MayewsKi, L.D. Meeker, M.S. TwickLeR, S.I. Whitlow \&

(C) Antiquity Publications Ltd, 2018 
I.I. Pittalwala. 1997. Bipolar changes in atmospheric circulation during the Little Ice Age. Science 277: 1294-96. https://doi.org/10.1126/science.277.5330.1294

Kylander, M.E., D.J. Weiss,

A. Martinez-Cortizas, B. Spiro,

R. Garcia-Sanchez \& B.J. Coles. 2005. Refining the pre-industrial atmospheric $\mathrm{Pb}$ isotope evolution curve in Europe using an 8000-year-old peat core from NW Spain. Earth and Planetary Science Letters 240: 467-85. https://doi.org/10.1016/j.epsl.2005.09.024

Lafaurie, J. \& J. Pilet-Lemière. 2003. Monnaies $d u$ haut Moyen Âge découvertes en France (Ve-VIIIe siècles) (Cahiers Ernest-Babelon 8). Paris: Éditions de CNRS.

LebecQ, S., B. Béthouart \& L. Verslype. 2010. Quentovic. Environnement, archéologie, histoire. Villeneuve d'Ascq: Centre de gestion de l'édition scientifique.

Le Roux, G., D. Weiss, J. Grattan, N. Givelet, M. Krachler, A. Cherbukin, N. Rausch, B. Ковеr \& W. Sнотүк. 2004. Identifying the sources and timing of ancient and medieval atmospheric lead pollution in England using a peat profile from Lindow Bog, Manchester. Journal of Environmental Monitoring 6: 502-10. https://doi.org/10.1039/B401500B

Leroy, B. 2009. Les monnaies de type anglo-saxon dans le Nord de la Gaule mérovingienne, in J. Soulat (ed.) Le matériel archéologique de type saxon et anglo-saxon en Gaule mérovingienne: 198 202. Saint-Germain-en-Laye: AFAM.

L'Héritier, M., S. Baron, L. Cassayre \& F. TÉREYGEOL. 2015. Bismuth behavior during ancient processes of silver-lead production. Journal of Archaeological Science 57: 56-68. https://doi.org/10.1016/j.jas.2015.02.002

Loveluck, C. 1995. Acculturation, migration and exchange: the formation of an Anglo-Saxon society in the English Peak District, 400-700 $\mathrm{AD}$, in J. Bintliff \& H. Hamerow (ed.) Europe between Late Antiquity and the Middle Ages: recent archaeological and historical research in Western and Southern Europe (British Archaeological Reports International series 617): 84-98. Oxford: Tempus Reparatum.

- 2013. Northwest Europe in the Early Middle Ages, c. AD 600-1150. A comparative archaeology. Cambridge: Cambridge University Press.

Luongo, M., A.V. Kurbatov, T. Erhardt, P.A. MAYewski, M. McCormick, A.F. More,

(C) Antiquity Publications Ltd, 2018
N.E. Spaulding, S.D. Wheatley, M.G. Yates \& P.D. Bohleber. 2017. Possible Icelandic tephra found in European Colle Gnifetti glacier. Geochemistry, Geophysics, Geosystems 18: 3904-09. https://doi.org/10.1002/2017GC007022

Malcolm, G., D. Bowsher \& R. Cowie. 2003. Middle Saxon London: excavations at the Royal Opera House, 1989-1999 (MOLAS Monograph 15). London: Museum of London.

Martinez-Cortizas, A., L. López-Merino, R. Bindler, T. Mighall \& M. Kylander. 2013. Atmospheric Pb pollution in N Iberia during the Late Iron Age/Roman times reconstructed using the high-resolution record of La Molina mire (Asturias, Spain). Journal of Paleolimnology 50: 71-86. https://doi.org/10.1007/s10933-013-9705-y

MayewsKi, P.A., L.D. Meeker, M.C. Morrison, M.S. Twickler, S.I. Whitlow, K.K. Ferland, D.A. Meese, M.R. Legrand \& J.P. Steffensen. 1993. Greenland ice core 'signal' characteristics: an expanded view of climate change. Journal of Geophysical Research 98(D7): 12839-47. https://doi.org/10.1029/93JD01085

McСormick, M. 2001. Origins of the European economy. Communications and commerce AD 300900. Cambridge: Cambridge University Press.

- 2018. En fin de compte: micro-archéologie, numismatique quantitative et systèmes d'information géographique, in M. Bompaire \& G. Sarah (ed.) Mine, metal, monnaie, Melle. Les voies de la quantification de l'histoire monétaire du haut Moyen Âge: 421-48. Geneva: Droz.

MetCalf, D.M. 2006. Monetary circulation in Merovingian Gaul, 561-674. A propos Cahiers Ernest Babelon 8. Revue numismatique 162: 33793. https://doi.org/10.3406/numi.2006.2813

Metcalf, D.M. \& J.P. Northover. 1989. Coinage alloys from the time of Offa and Charlemagne to c. 864. Numismatic Chronicle 149: 101-20.

More, A.F., N.E. Spaulding, P. Bohleber, M.J. Handley, H. Hoffmann, E.V. Korotkikh, A.V. Kurbatov, C.P. Loveluck, S. SneEd, M. McCormick \& P.A. MAYEwSKI. 2017. Next-generation ice core technology reveals true minimum natural levels of lead $(\mathrm{Pb})$ in the atmosphere: insights from the Black Death. GeoHealth 1(4).

NAISMith, R. 2014. The social significance of monetization in the Early Middle Ages. 
Past \& Present 223: 3-39.

https://doi.org/10.1093/pastj/gtu004

Nelson, J.L. 1992. Charles the Bald. London: Longman.

Pedersen, U., T. Andersen, S. Simonsen \&

M. Erambert. 2016. Lead isotope analysis of pewter mounts from the Viking ship burial at Gokstad: on the origin and use of raw materials. Archaeometry 58: 148-63.

https://doi.org/10.1111/arcm.12222

Preunkert, S., D. Wagennach, M. Legrand \& C. Vincent. 2000. Col du Dôme (Mt Blanc Massif, French Alps) suitability for ice core studies in relation with past atmospheric chemistry over Europe. Tellus B: Chemical and Physical Meteorology 52: 993-1012. https://doi.org/10.3402/tellusb.v52i3.17081

Schwikowski, M., C. Barbante, T. Doering, H.W. Gaeggeler, C. Boutron, U. Shotterer, L. Tobler, K. Van de Velde, C. Ferrari, G. Cozzi, K. Rosman \& P. Cescon. 2004. Post $-17^{\text {th }}$-century changes of European lead emissions recorded in high-altitude alpine snow and ice. Environmental Science and Technology 38: 957-64. https://doi.org/10.1021/es034715o

SCull, C. 2013. Implications for Anglo-Saxon economic history, in J. Hines \& A. Bayliss (ed.) Anglo-Saxon graves and grave-goods of the sixth and seventh centuries $A D$ : a chronological framework (Society for Medieval Archaeology Monograph 33): 545-48. Leeds: Maney.

Scull, C. \& J. Naylor. 2016. Sceattas in AngloSaxon graves. Medieval Archaeology 60: 205-41. https://doi.org/10.1080/00766097.2016. 1221262

SigL, M., J.R. McConnell, L. Layman, O. Maselli, K. McGwire, D. Pasteris, D. Dahl-Jensen, J.P. StefFensen, B. Vinther, R. Edwards, R. Mulvaney \& S. Kipfstuhl. 2013. A new bipolar ice core record of volcanism from WAIS Divide and NEEM and implications for climate forcing of the last 2000 years. Journal of Geophysical Research: Atmospheres 118: 115169. https://doi.org/10.1029/2012JD018603

SIGL, M. et al. 2015. Timing and climate forcing of volcanic eruptions for the past 2,500 years. Nature 523: 543-49. https://doi.org/10.1038/nature14565

Sneed, S., P.A. MaYewski, W.G. SAYre, M.J. Handley, A.V. Kurbatov, K.C. Taylor, P. Bohleber, D. Wagenbach, T. Erhardt $\&$ N.E. Spaulding. 2015. New LA-ICP-MS cryocell and calibration technique for sub-millimeter analysis of ice cores. Journal of Glaciology 61: 233-42. https://doi.org/10.3189/2015JoG14J139

Téreygeol, F. 2007. Production and circulation of silver and secondary products (lead and glass) from Frankish royal silver mines at Melle (eighth to tenth century), in J. Henning (ed.) Post-Roman towns, trade and settlement in Europe and Byzantium. Volume 1: the heirs of the Roman west. 123-34. Berlin: Walter De Gruyter.

- 2010. Y-a-t-il un lien entre la mise en exploitation des mines d'argent de Melle (Deux-Sèvres) et le passage au monométallisme argent vers 675 ? in L. Bourgeois (ed.) Wisigoths et Francs autour de la bataille de Vouillé (507). Recherches récentes sur le haut Moyen Âge dans le centre-ouest de la France: 251-61. Saint-Germain-en-Laye: AFAM.

Thordason, T., D.J. Miller, G. Larsen, S. Self \& H. Sigurdson. 2001. New estimates of sulfur degassing and atmospheric mass-loading by the 934 AD Eldgjá eruption, Iceland. Journal of Volcanology and Geothermal Research 108: 33-54. https://doi.org/10.1016/S0377-0273(00)00277-8

Williams, G. 2010. Anglo-Saxon gold coinage, part 1: the transition from Roman to Anglo-Saxon coinage. British Numismatic Journal 80: $51-75$.

Received: 27 November 2017; Revised: 3 May 2018; Accepted: 22 May 2018

(C) Antiquity Publications Ltd, 2018 